\title{
Experimental bath infection with Flavobacterium psychrophilum, inducing typical signs of rainbow trout Oncorhynchus mykiss fry syndrome
}

\author{
Masatoshi Aokii ${ }^{1}$, Motoki Kondo ${ }^{1}$, Kenji Kawai ${ }^{1}$, Syun-ichirou Oshima ${ }^{2, *}$ \\ ${ }^{1}$ Fish Disease Laboratory, Department of Aquaculture, Kochi University, Nankoku, Kochi 783-8502, Japan \\ ${ }^{2}$ Laboratory of Cell Structure and Function, Division of Marine Bioresource Science, Graduate School of Kuroshio Science, \\ Kochi University, Nankoku, Kochi 783-8502, Japan
}

\begin{abstract}
Flavobacterium psychrophilum infection in salmonid fish, known as rainbow trout fry syndrome (RTFS) or bacterial coldwater disease (BCWD), is widespread in fish farms and natural waters. Despite many studies in which attempts at infection were made, an adequate method of infection has not yet been established. In this study, we evaluated a bath infection method in which we used bacteria at different stages of growth in the infection of rainbow trout Oncorhynchus mykiss. Rainbow trout with a mean body weight of 1.3 or $5.6 \mathrm{~g}$, respectively, were infected by immersion in a bacterial suspension at different stages of growth (18 to $66 \mathrm{~h}$ shaking culture at $15^{\circ} \mathrm{C}$ ). The fish immersed in a logarithmic phase culture showed higher mortality than those in other culture phases. Indeed, 1.3 and $5.6 \mathrm{~g}$ fish showed typical clinical signs including ulcerative tissue of the trunk and lack of caudal fin edge. F. psychrophilum was detected by immunohistochemistry (IHC) in these tissue samples. These results indicate that experimental bath infection using a logarithmic phase bacterial solution is the most appropriate method for studies of infectious mechanisms.
\end{abstract}

KEY WORDS: Flavobacterium psychrophilum - Logarithmic phase - Bath challenge - Virulence Bacterial coldwater disease $\cdot$ Rainbow trout fry syndrome

\section{INTRODUCTION}

Flavobacterium psychrophilum has been known as the causative bacterium of a disease in juvenile salmonid fish since the 1940s (Borg 1960). The disease has been variously designated as a low-temperature disease (Borg 1960), saddleback disease (Borg 1960, Holt 1987), bacterial coldwater disease (Holt 1987), fry mortality syndrome (Lorenzen et al. 1991) and rainbow trout fry syndrome (Madsen \& Dalsgaard 1998). The disease occurs in most areas of the world including the USA, Canada, Chile, Australia, Japan, Korea and several European countries (Holt 1987, Santos et al. 1992, Toranzo \& Barja 1993, Wakabayashi et al. 1994, Bustos et al. 1995, Schmidtke \& Carson 1995) causing serious mortalities and, hence, severe economic losses in hatcheries and farms. Naturally infected rainbow trout Oncorhynchus mykiss show external signs of ulcers on the body trunk and the caudal fin edge, exophthalmia and haemorrhage on the gills, and internal signs of anaemia, necrotic myositis, necrotic scleritis and cephalic osteochondritis (Holt et al. 1993, Ostland et al. 1997). The appearance of antibiotic-resistant F. psychrophilum (Kondo et al. 2001a) and the difficulty of treatment of fish stocks in natural waters has promoted vaccine study (Kondo et al. 2003, LaFrentz et al. 2004).

Several attempts have been made, using various challenge models, to study the pathogenesis of Flavobacterium psychrophilum. Rainbow trout Oncorhynchus mykiss and other salmonids have shown high mortality following intraperitoneal, intramuscular or subcutaneous injections used to investigate the virulence of the bacterium and to establish a challenge method for use in vaccine trials (Borg 1960, Holt 1987, Austin et al. 1992, Lorenzen 1994, Rangdale 1995, Madsen \& Dalsgaard 1999, Garcia et al. 2000, Decostere et al. 2001). However, 
the direct delivery of bacteria into host internal tissue by injection is not a natural route of infection and bypasses the intrinsic defense mechanism of the mucus, skin, gills and gut of fish. Cohabitation, contact and immersion infection models have attempted to mimic the natural route of infection (Rangdale 1995, Madsen \& Dalsgaard 1999, Decostere et al. 2000, Garcia et al. 2000, Madetoja et al. 2000, Liu et al. 2001, Busch et al. 2003). Some researchers have performed immersion experiments, most of them reporting successful but unreproducible results (Madsen \& Dalsgaard 1999, Garcia et al. 2000). Reproducible bath infection for ayu Plecoglossus altivelis, using a logarithmic culture phase of F. psychrophilum and without stressing the fish, has previously been reported (Kondo et al. 2001b, 2003).

In the present study, we attempted a bath infection model for juvenile rainbow trout Oncorhynchus mykiss using Flavobacterium psychrophilum in the logarithmic, stationary and death culture phases, and obtained a high mortality and clinical signs similar to natural infection using the logarithmic culture phase. We suggest that this is a successful protocol for bath infection of rainbow trout.

\section{MATERIALS AND METHODS}

Bacterial strain and growth condition. Flavobacterium psychrophilum strain NCIMB1947 isolated in 1948 from the kidney of the coho salmon Oncorhynchus kisutch in the USA was used for a bath challenge. This strain represented the serotype $\mathrm{Fp}^{\mathrm{T}}$ (O1) (Izumi \& Wakabayashi 1994, Lorenzen \& Olesen 1997). This bacterium was passed 5 times in rainbow trout Oncorhynchus mykiss before experiments. The bacterium was pre-cultured in $50 \mathrm{ml}$ modified cytophaga broth (MCYT; $0.2 \%$ trypton, $0.05 \%$ yeast extract, $0.02 \%$ tuna extract [Kyokuto], $0.02 \% \mathrm{CH}_{3} \mathrm{COONa}, 0.02 \%$ $\mathrm{CaCl}_{2}$ ) at $15^{\circ} \mathrm{C}$ for $48 \mathrm{~h}$, and then $2.5 \mathrm{ml}$ of the culture was inoculated into $1000 \mathrm{ml} \mathrm{MCYT} \mathrm{broth.} \mathrm{The} \mathrm{bac-}$ terium was cultured by shaking $\left(100 \mathrm{rpm}\right.$ at $\left.15^{\circ} \mathrm{C}\right)$. Growth phase was monitored by measuring the absorbance at $600 \mathrm{~nm}$ (0-2001, Hitachi), and the viable number of bacteria was cultured on MCYT agar using the agar spread method every $6 \mathrm{~h}$ after inoculation.

Experimental fish. Two month old rainbow trout Oncorhynchus mykiss, (mean weight $1.3 \mathrm{~g}$ ), and $10 \mathrm{mo}$ old rainbow trout (mean weight $5.6 \mathrm{~g}$ ) were obtained from a local fish farm (Iwana-so, Ehime prefecture, Japan) with no previous recorded occurrence of infection with Flavobacterium psychrophilum. Ten fish were tested for the presence of F. psychrophilum before experiments. The fish were kept in a $3.3 \mathrm{~m}^{3}$ concrete tank with continuously flowing well water at 17 to $18^{\circ} \mathrm{C}$. The fish were acclimatized at $17^{\circ} \mathrm{C}$ in a cir- culating tank for at least $5 \mathrm{~d}$ and were fed dry commercial pellets (Nissui), corresponding to $3 \%$ of fish body weight, until the end of the experiment.

Bath challenge. The cultures for 18, 24, 48 and $66 \mathrm{~h}$ coincided with the middle logarithmic, late logarithmic, stationary and death phases for Flavobacterium psychrophilum (see Fig. 1). The concentration of bacterium at $18 \mathrm{~h}$ is approximately $10^{7}$, at $24 \mathrm{~h} 10^{8}$, at $48 \mathrm{~h}$ $10^{9}$ and at $66 \mathrm{~h} 10^{8} \mathrm{CFU} \mathrm{ml}{ }^{-1}$. Each of the 8 infection groups consisted of approximately 100 fish. Five thousand $\mathrm{ml}$ of the bacterial culture was harvested by centrifugation $\left(1000 \times g\right.$ for $15 \mathrm{~min}$ at $\left.4^{\circ} \mathrm{C}\right)$ and resuspended in $250 \mathrm{ml}$ of the fresh MYCT broth and $4750 \mathrm{ml}$ tap water. Bath infection was carried out by immersion in aerated well water (for $1 \mathrm{~h}$ at $17^{\circ} \mathrm{C}$ ) in which both groups (1.3 g and $5.6 \mathrm{~g}$ ) were immersed and cultured for $18 \mathrm{~h}, 24 \mathrm{~h}, 48 \mathrm{~h}$ and $66 \mathrm{~h}$. These groups were classified as $18 \mathrm{~h}-1.3 \mathrm{~g}, 24 \mathrm{~h}-1.3 \mathrm{~g}, 48 \mathrm{~h}-11.3 \mathrm{~g}, 66 \mathrm{~h}-1.3 \mathrm{~g}$, $18 \mathrm{~h}-5.6 \mathrm{~g}, 24 \mathrm{~h}-5.6 \mathrm{~g}, 48 \mathrm{~h}-5.6 \mathrm{~g}$ and $66 \mathrm{~h}-5.6 \mathrm{~g}$ (see Table 1). Fish from the control group were immersed for $1 \mathrm{~h}$ in sterile MYCT broth diluted 1:20 with well water. The final concentration of bacterium used ininfection is shown in Table 1. After immersion infection, fish were reared in circulating tanks at $17^{\circ} \mathrm{C}$ for $14 \mathrm{~d}$.

Detection of Flavobacterium psychrophilum after experimental bath infection. Fish from both infected and control groups were killed by a blow to the head and tissues imprinted onto a glass slide. The presence of bacteria on the slide was confirmed by methylene blue staining. The presence of F. psychrophilum was confirmed by immunohistochemistry (IHC) using anti-F. psychrophilum NCIMB1947 strain rabbit serum. Rabbit serum directed against F. psychrophilum NCIMB1947 was used as a primary antibody (dilution 1:200). The binding of immunoglobulins by F. psychrophilum cells was shown using anti-goat immunoglobulins directed against rabbit antibody (Wako). The secondary antibody was conjugated with fluorescein isothiocyanate (FITC). FITC-labelled cells were observed under a fluorescence microscope.

Statistical analysis. Differences in cumulative mortalities were analyzed using the chi-square test (Excel, Microsoft).

\section{RESULTS}

\section{Bath infection test conditions}

Fig. 1 shows the growth curve obtained from the shaken culture of Flavobacterium psychrophilum NCIMB1947 strain in MCYT broth. This result shows that the bacterial solution reached a logarithmic phase at 6 to $30 \mathrm{~h}$ after inoculation when the viable counts were approximately $10^{4.0}$ to $10^{8.0} \mathrm{CFU} \mathrm{ml}^{-1}$. For convenience, we divided the logarithmic phase into a middle- and a late 


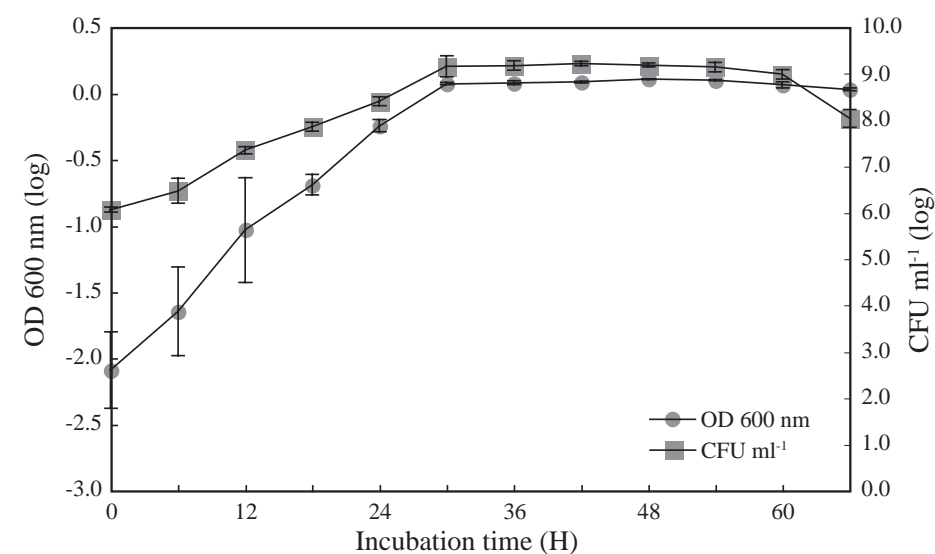

Fig. 1. Flavobacterium psychrophilum. Growth curve for bacteria cultured in modified cytophaga broth with shaking at $15^{\circ} \mathrm{C}$. $\mathrm{OD}=$ optical density

logarithmic phase according to cell number. The culture reached a stationary phase at $30 \mathrm{~h}$ after inoculation, when the viable count was approximately $10^{9.0} \mathrm{CFU}$ $\mathrm{ml}^{-1}$. The bacterial solution at $66 \mathrm{~h}$ after inoculation showed a decrease in CFU (death phase). From this culture, bacterial solution at $18 \mathrm{~h}$ (middle logarithmic phase), $24 \mathrm{~h}$ (late logarithmic phase), $48 \mathrm{~h}$ (stationary phase) and $66 \mathrm{~h}$ (death phase) was used for the challenge.

\section{Bath challenge}

Table 1 and Fig. 2 show the results of the bath challenge experiments. The Challenge 1 results show that the cumulative mortality rate of the $1.3 \mathrm{~g}$ fish in the $18 \mathrm{~h}$ and $24 \mathrm{~h}$ groups was significantly different from that of the $1.3 \mathrm{~g}$ fish in the $48 \mathrm{~h}$ group and the control group (chi-square test, p < 0.01).

Table 1. Flavobacterium psychrophilum. Cumulative mortalities in the bath challenge test. Fish were immersed in aerated well

\begin{tabular}{|c|c|c|c|c|c|}
\hline Group & $\begin{array}{l}\text { Mean body } \\
\text { weight (g) }\end{array}$ & $\begin{array}{l}\text { F. psychrophilum } \\
\text { culture time }(\mathrm{h})\end{array}$ & 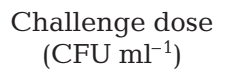 & $\begin{array}{c}\text { Dead fish / } \\
\text { challenged fish }\end{array}$ & $\begin{array}{l}\text { Cumulative mortality } \\
14 \text { d post challenge }(\%)\end{array}$ \\
\hline \multicolumn{6}{|l|}{ Challenge 1} \\
\hline $18 \mathrm{~h}-1.3 \mathrm{~g}$ & 1.4 & 18 & $2.0 \times 10^{7}$ & $34 / 108$ & $31.5^{\mathrm{a}}$ \\
\hline $24 \mathrm{~h}-1.3 \mathrm{~g}$ & 1.1 & 24 & $8.5 \times 10^{7}$ & $53 / 91$ & $58.2^{\mathrm{a}}$ \\
\hline $48 \mathrm{~h}-1.3 \mathrm{~g}$ & 1.4 & 48 & $3.4 \times 10^{8}$ & 0/101 & 0.0 \\
\hline $66 \mathrm{~h}-1.3 \mathrm{~g}$ & 1.3 & 66 & $2.0 \times 10^{6}$ & $0 / 105$ & 0.0 \\
\hline Control-1.3 g & 1.4 & - & - & $0 / 95$ & 0.0 \\
\hline \multicolumn{6}{|l|}{ Challenge 2} \\
\hline $18 \mathrm{~h}-5.6 \mathrm{~g}$ & 5.3 & 18 & $2.0 \times 10^{7}$ & $41 / 117$ & $35.0^{\mathrm{b}}$ \\
\hline $24 \mathrm{~h}-5.6 \mathrm{~g}$ & 6.4 & 24 & $8.5 \times 10^{7}$ & $31 / 82$ & $37.8^{\mathrm{b}}$ \\
\hline $48 \mathrm{~h}-5.6 \mathrm{~g}$ & 6.2 & 48 & $3.4 \times 10^{8}$ & $6 / 87$ & $6.9^{\mathrm{b}}$ \\
\hline $66 \mathrm{~h}-5.6 \mathrm{~g}$ & 5.6 & 66 & $2.0 \times 10^{6}$ & $0 / 107$ & 0.0 \\
\hline Control-5.6 g & 5.4 & - & - & 0/108 & 0.0 \\
\hline
\end{tabular}

The Challenge 2 results show that the mortality rate of the $5.6 \mathrm{~g}$ fish in the $18 \mathrm{~h}, 24 \mathrm{~h}$ and $48 \mathrm{~h}$ groups was significantly different from that of the 5.6 g control group (chi-square test, $\mathrm{p}<0.01$ ). The $5.6 \mathrm{~g}$ fish in the $18 \mathrm{~h}$ and $24 \mathrm{~h}$ groups were significantly different from those in the $48 \mathrm{~h}$ group (chi-square test, $\mathrm{p}<0.01)$.

\section{water containing bacteria. See 'Materials and methods' for more details}

Fig. 2. Flavobacterium psychrophilum. Cumulative mortalities of rainbow trout by experimental bath infection: (匹) challenge with $18 \mathrm{~h}$ cultured bacteria; $(\bullet)$ challenge with $24 \mathrm{~h}$ cultured bacteria; cultured bacteria; $(\mathrm{O})$ control. The letters a and b indicate significant difference $(p<0.01)$ compared with the results for the control group
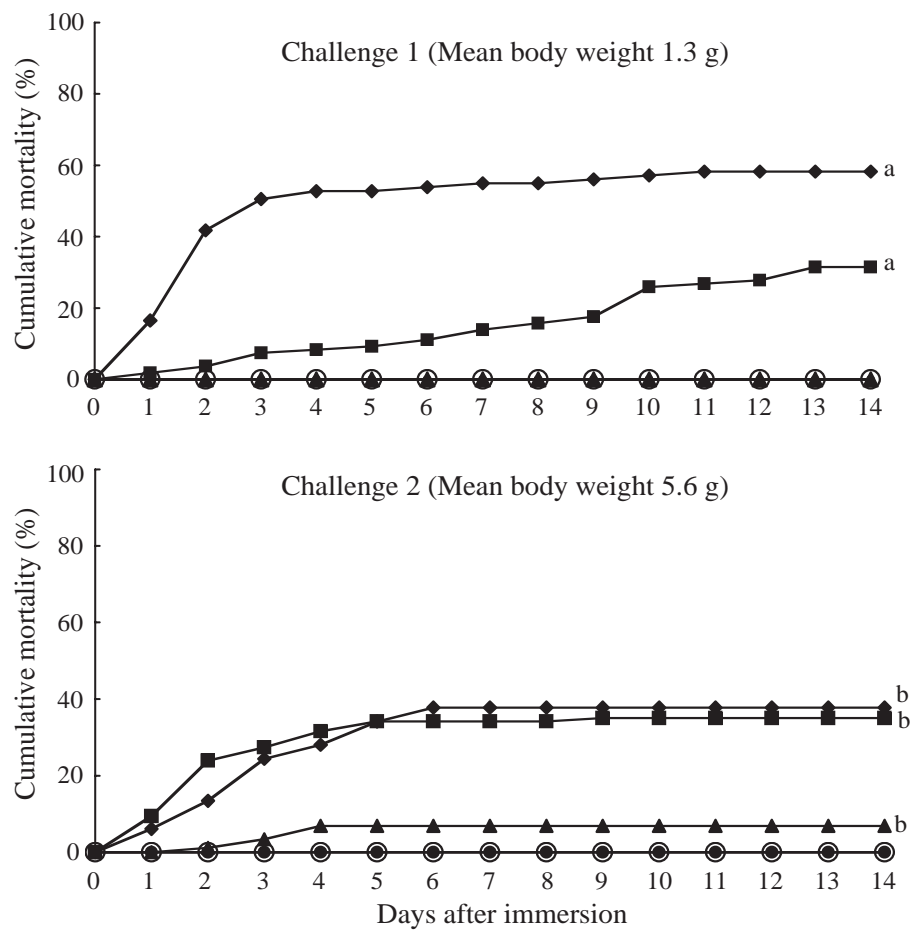


\section{Clinical signs}

In both weight categories (1.3 and $5.6 \mathrm{~g}$ ) the fish in the $24 \mathrm{~h}$ groups began to die on Day 1 post challenge and mortalities continued for the next 6 to $11 \mathrm{~d}$. All dead fish in these groups showed the following typical signs of disease: ulcers on the body trunk and partial lack of caudal fin edge (Fig. 3). Infected $1.3 \mathrm{~g}$ fish from the $24 \mathrm{~h}$ group showed partial lack of the operculum (Fig. 3B). Internally, anaemia was observed in the form of pale gills, kidney, intestine, and liver (data not shown). Fish in both weight categories from the $18 \mathrm{~h}$ groups showed signs similar to those of the respective 24 h groups. However, in other culture phases and control groups, disease and internal signs were not observed.

\section{Detection of Flavobacterium psychrophilum in tissue samples}

In dead fish infected with logarithmic phase bacterial solutions, numerous bacteria were observed in ulcerative tissue, such as the surface of the trunk and caudal peduncle. Flavobacterium psychrophilum was detected by IHC in ulcerative tissue such as the surface of the trunk, caudal fin edge, spleen and kidney (Fig. 4). Numerous F. psychrophilum cells were observed on the body trunk and caudal fin edge. In the spleen and kid- ney, there were few bacteria. F. psychrophilum were not observed on any site of the control fish.

\section{DISCUSSION}

In order to develop a practical vaccine against RTFS, setting up a reproducible experimental bath infection is important because injecting bacteria into the host's body is not a natural route of Flavobacterium psychrophilum infection. The bath infection method, however, resembles a natural infection and thus seems to be the best infection method. Previous researchers have performed immersion experiments, most of them reporting that experimental fish die but that these results are not reproducible (Madsen \& Dalsgaard 1999, Garcia et al. 2000). Kondo et al. (2003) showed that reproducible bath infection using the logarithmic phase of F. psychrophilum strain G3724 in ayu Plecoglossus altivelis is possible. In the present study, we investigated the same infection method in rainbow trout fry. F. psychrophilum strain NCIMB1947 has been well characterized (Secades et al. 2001), and therefore, this strain is a practical and useful strain in the study of pathogenic mechanisms. However, this strain belongs to $\mathrm{Fp}^{\mathrm{T}}$. Lorenzen \& Olesen (1997) suggested that isolates belonging to the serotype $\mathrm{Fp}^{\mathrm{T}}$ were less virulent than other isolates. We reported that loga-
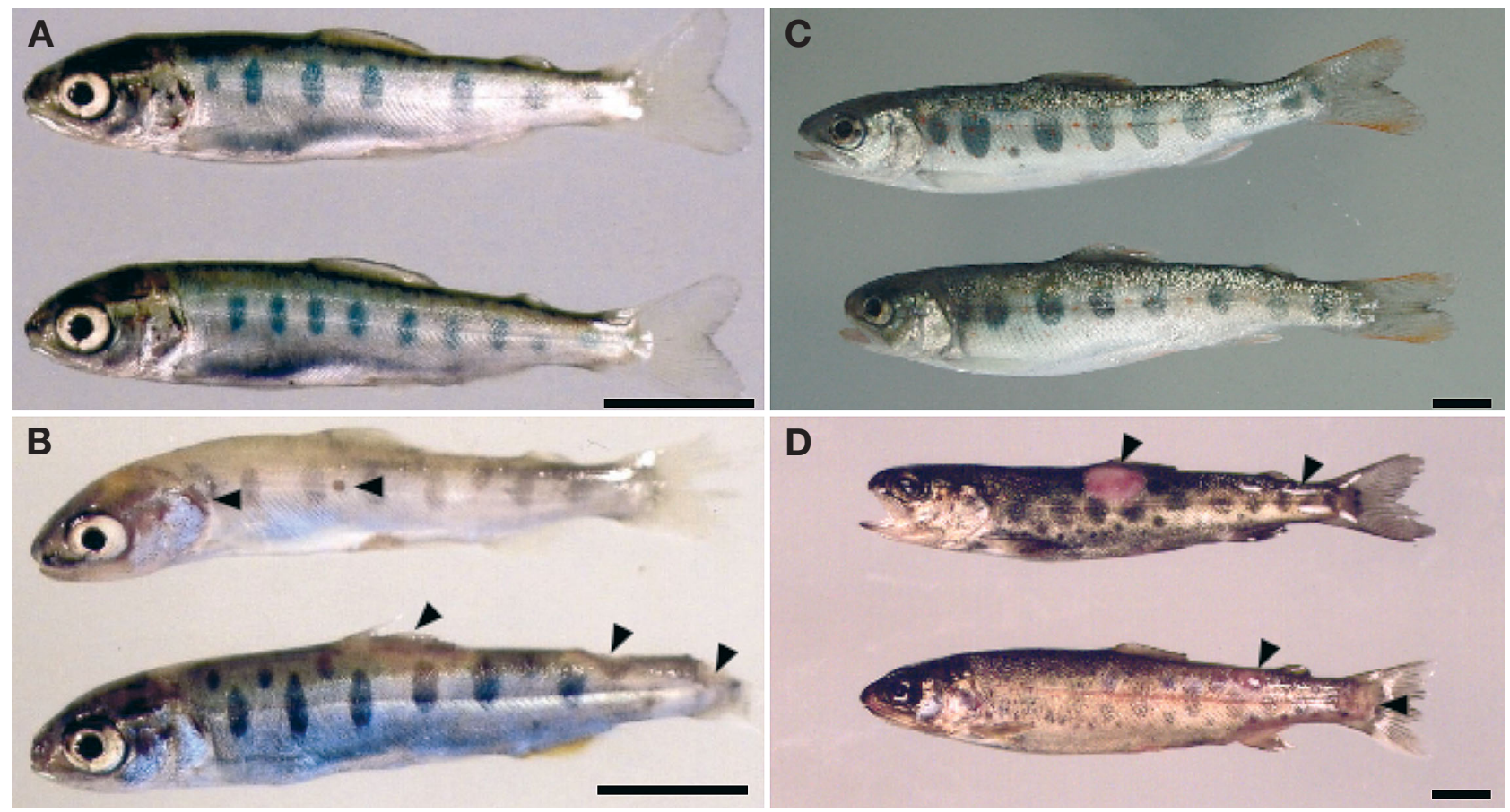

Fig. 3. Typical signs of rainbow trout fry syndrome. (A) Control for $1.3 \mathrm{~g}$ group fish; (B) infected $1.3 \mathrm{~g}$ group fish; (C) control for $5.6 \mathrm{~g}$ group fish; (D) infected $5.6 \mathrm{~g}$ group fish. Arrowheads indicate partial lack of operculum, ulcers on the trunk and dorsal side and lack of fin edge. Scale bar $=10 \mathrm{~mm}$ 


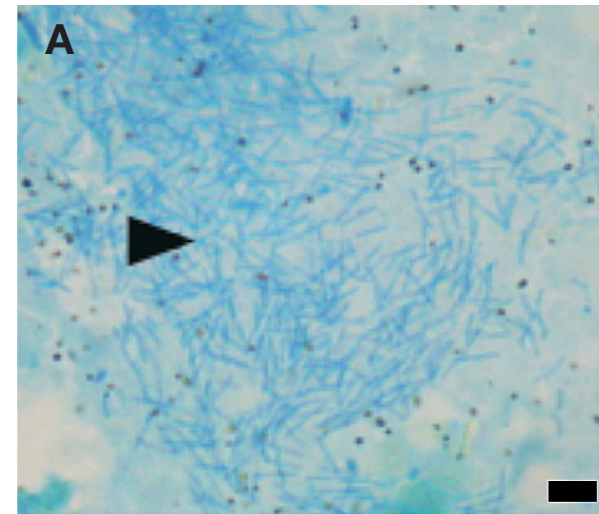

E

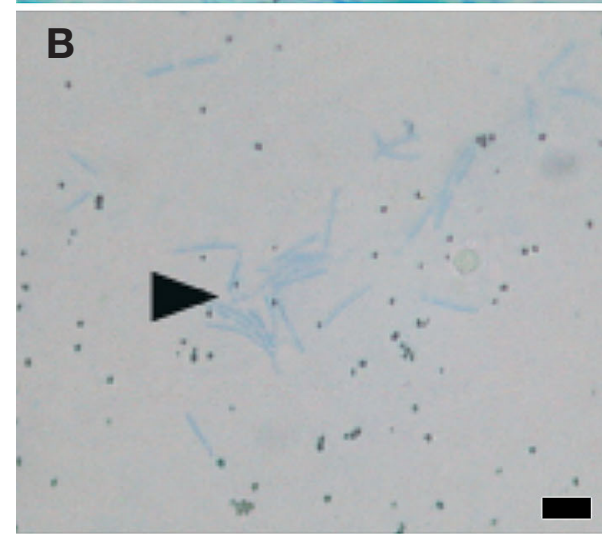

F

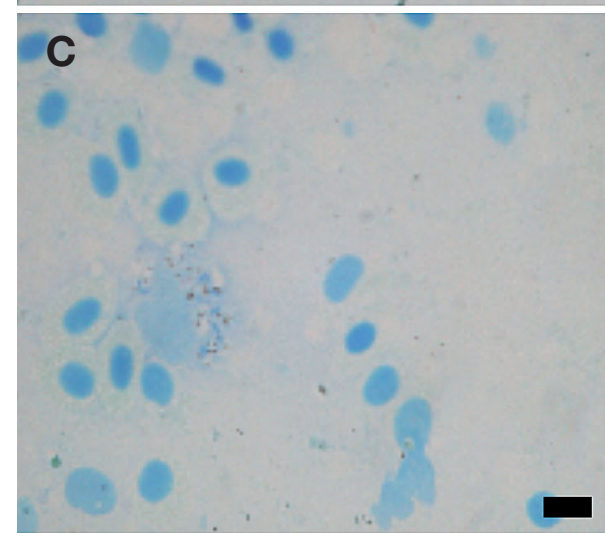

G

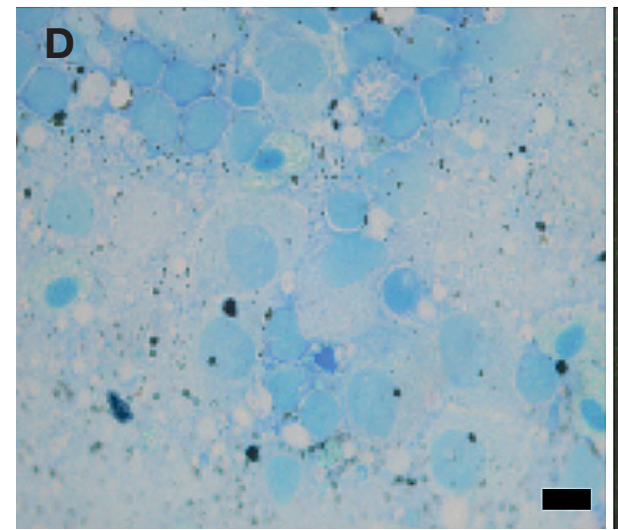

H

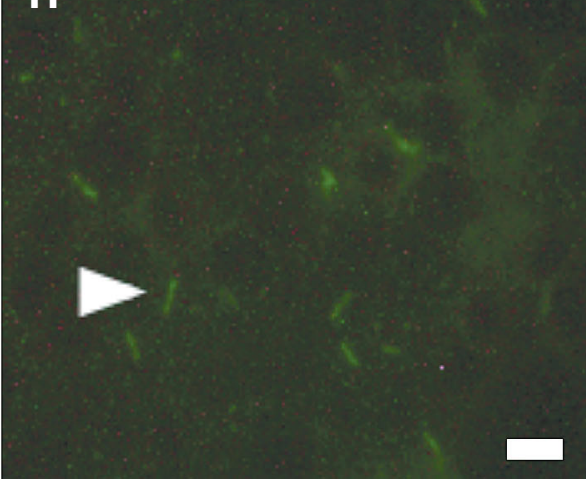

Fig. 4. Tissue imprint of rainbow trout after bath challenge. (A) and (E): trunk lesion; (B) and (F): caudal fin; (C) and (G): spleen; (D) and (H): kidney. Black arrowheads show rod-shaped bacteria (methylene blue stain). White arrowheads show Flavobacterium psychrophilum stained with anti-F. psychrophilum 1947 strain rabbit serum. Magnification $\times 1000(\mathrm{scale}$ bar $=2 \mu \mathrm{m})$ 
rithmic phase culture of $F$. psychrophilum strain G3724 has high virulence (Kondo et al. 2002, 2003); therefore, we examined whether the logarithmic phase of $F$. psychrophilum strain NCIMB1947 also has high virulence. At the beginning of this study, we determined the logarithmic, stationary and death phases of F. psychrophilum strain NCIMB1947. The growth curve of this strain showed logarithmic (6 to $30 \mathrm{~h})$, stationary (30 to $60 \mathrm{~h}$ ) and death phases (60 to $66 \mathrm{~h}$ ).

In this study, we demonstrated that Flavobacterium psychrophilum in the logarithmic culture phase caused higher mortality than the stationary and death phases (0 to $6.9 \%$ mortality) of rainbow trout fry Oncorhynchus mykiss (2 and 10 mo old). In a previous study we showed that cumulative mortality by bath infection achieved a maximum of $70 \%$ using logarithmic phase F. psychrophilum strain G3724 in ayu Plecoglossus altivelis (Kondo et al. 2003). Our findings conclude that F. psychrophilum strains G3724 and NCIMB1947 in the logarithmic phase are highly virulent in both ayu (Kondo et al. 2003) and rainbow trout. In this study, we attempted to evaluate in detail the virulence of F. psychrophilum in the logarithmic, middle and late logarithmic phases. Our results indicated that the late logarithmic phase $(24 \mathrm{~h})$ has a higher virulence $(58.2 \%$ mortality) than the middle logarithmic phase $(18 \mathrm{~h}$; $31.5 \%$ mortality) in the mean body weight of $1.3 \mathrm{~g}$ group. However, the bacterial number in the late logarithmic phase differed from the middle logarithmic phase concentration. Therefore, our results did not reflect the virulence of these 2 phases, indicating that further study of the virulence of middle and late logarithmic phases is needed. Additionally, the mortality rate in the mean body weight of $5.6 \mathrm{~g}$ group was significantly different from the control group.

Rainbow trout Oncorhynchus mykiss naturally infected in hatcheries usually show clinical signs such as trunk ulcers, lack of caudal fin edge, anaemia, exophthalmia and haemorrhage of the gills, necrotic myositis, necrotic scleritis and cephalic osteochondritis (Holt et al. 1993, Ostland et al. 1997). In the present study, trunk ulcers, lack of caudal fin edge, anaemia in the form of pale gills, kidney, intestine and liver were found in the mean body weight of 1.3 and $5.6 \mathrm{~g}$ groups. Numerous bacteria were identified in the affected parts of the body surface. Therefore, our bath infection mimicked natural infection of RTFS. The mean body weight of $1.3 \mathrm{~g}$ group showed more severe signs than the mean body weight of $5.6 \mathrm{~g}$ group. Madetoja et al. (2000) found that size differences affect the level of immunocompetence in rainbow trout. In this study, the mortality rate for the mean body weight of $1.3 \mathrm{~g}$ group of low-level immunocompetence was higher than for the mean body weight of $5.6 \mathrm{~g}$ group, thus reflecting the findings of studies which determined that RTFS almostly always occurs in small rainbow trout (0.2 to 2.0 g) (Santos et al. 1992, Nematollahi et al. 2003).

In conclusion, we believe this is the first study to succeed in infecting fish using a bath infection method with logarithmic phase bacteria and avoiding the stress of injection. Logarithmic phase culture showed a high mortality of fish, which demonstrated typical signs of disease and numerous bacteria on body surface tissues. The experimental bath infection described here using a logarithmic phase bacterial solution may be a successful method in evaluating the pathogenesis of fish disease and the development of a candidate vaccine.

Acknowledgements. This research was supported by a Regional Science Promotion Program grant from the Japan Science and Technology Agency (JST), and a New Energy and Industrial Technology Development Organization (NEDO) grant. We thank Y. Nakatuka for his technical assistance and advice.

\section{LITERATURE CITED}

Austin B, Stobie M, Gonzales CJ, Curry JI, McLoughlin MF (1992) Recovery of Janthinobacterium lividum from rainbow trout, Oncorhynchus mykiss (Walbaum), in Northern Ireland and Scotland. J Fish Dis 15:357-359

Borg AF (1960) Studies on myxobacterium associated with diseases in salmonid fishes. Am Assoc Adv Sci Wildl Dis 8:1-85

Busch S, Dalsgaard I, Buchmann K (2003) Concomitant exposure of rainbow trout fry to Gyrodactylus derjavini and Flavobacterium psychrophilum: effects on infection and mortality of host. Vet Parasitol 117:117-122

Bustos PA, Calbuyahue J, Montaña J, Opazo B, Entrala P, Solervisenc R (1995) First isolation of Flexibacter psychrophilus, as causative agent of rainbow trout fry mortality syndrome (RTFS), producing rainbow trout mortality in Chile. Bull Eur Assoc Fish Pathol 15:162-164

Decostere A, Lammens M, Haesebrouck F (2000) Difficulties in experimental infection studies with Flavobacterium psychrophilum in rainbow trout (Oncorhynchus mykiss) using immersion, oral and anal challenges. Res Vet Sci 69:165-169

Decostere A, D'Haese E, Lammens M, Nelis H, Haesebrouck F (2001) In vivo study of phagocytosis, intracellular survival and multiplication of Flavobacterium psychrophilum in rainbow trout, Oncorhynchus mykiss (Walbaum), spleen phagocytes. J Fish Dis 24:481-487

Garcia C, Pozet F, Michel C (2000) Standardization of experimental infection with Flavobacterium psychrophilum, the agent of rainbow trout Oncorhynchus mykiss fry mortality syndrome. Dis Aquat Org 42:191-197

Holt RA (1987) Cytophaga psychrophila, the causative agent of bacterial cold-water disease in salmonid Fish. PhD thesis, Oregon State University, Corvallis, OR

Holt RA, Rohovec JS, Fryer JL (1993) Bacterial coldwater disease. In: Inglis V, Roberts RJ, Bromange NR (eds) Bacterial disease of fish. Blackwell Scientific, Oxford, p 2-23

Izumi S, Wakabayashi H (1997) Use of PCR to detect Cytochaga psychrophila from apparently healthy juvenile ayu and coho salmon eggs. Fish Pathol 32:169-173 
Kondo M, Kawai K, Jung SJ, Oshima S (2001a) Antimicrobial susceptibility of Flavobacterium psychrophilum isolated form cultured ayu Plecoglossus altivelis in Japan. J Fish Pathol 14:173-176

Kondo M, Kawai K, Yagyu K, Nakayama K, Kurohara K, Oshima S (2001b) Changes in the cell structure of Flavobacterium psychrophilum with length of culture. Microbiol Immunol 45:813-818

Kondo M, Kawai K, Kurohara K, Oshima S (2002) Adherence of Flavobacterium psychrophilum on the body surface of ayu Plecoglossus altivelis. Microbes Infect 4:279-283

Kondo M, Kenji K, Okabe M, Nakano N, Oshima S (2003) Efficacy of oral vaccine against bacterial coldwater disease in ayu Plecoglossus altivelis. Dis Aquat Org 55:261-263

LaFrentz BR, Lapatra SE, Jones GR, Cain KD (2004) Protective immunity in rainbow trout Oncorhynchus mykiss following immunization with distinct molecular mass fractions isolated from Flavobacterium psychrophilum. Dis Aquat Org 59:17-26

Liu H, Izumi S, Wakabayashi H (2001) Detection of Flavobacterium psychrophilum in various organs of ayu Plecoglossus altivelis by in situ hybridizaton. Fish Pathol 36:7-11

Lorenzen E (1994) Studies on Flavobacterium psychrophilus in relation to rainbow trout fry syndrome (RTSF). PhD thesis, National Veterinary Laboratory, Århus, and Royal Veterinary and Agricultural University, Copenhagen

Lorenzen E, Olesen NJ (1997) Characterization of isolates of Flavobacterium psychrophilum associated with coldwater disease or rainbow trout fry syndrome: serological studies. Dis Aquat Org 31:209-220

Lorenzen E, Dalsgaard I, From J, Hansen EM, Hørlyck V, Korsholm H, Mellergaard S, Olesen NJ (1991) Preliminary investigation of fry mortality syndrome in rainbow trout. Bull Eur Assoc Fish Pathol 11:77-79

Madetoja J, Nyman P, Wiklund T (2000) Flavobacterium psychrophilum, invasion into and shedding by rainbow trout Oncorhynchus mykiss. Dis Aquat Org 43:27-38

Madsen L, Dalsgaard I (1998) Characterization of Flavobac-

Editorial responsibility: David Bruno,

Aberdeen, UK terium psychrophilum; comparison of proteotypic activity and virulence of strains isolated from rainbow trout (Oncorhynchus mykiss). In: Barnes AC, Davidson GA, Hiney MP, McIntosh D (eds) Methodology in fish diseases research. Fisheries Reserch Services, Aberdeen, p 45-52

Madsen L, Dalsgaard I (1999) Reproducible methods for experimental infection with Flavobacterium psychrophilum in rainbow trout Oncorhynchus mykiss. Dis Aquat Org 36:169-176

Nematollahi A, Decostere A, Pasmans F, Haesebrouck (2003) Flavobacterium psychrophilum infections in salmonid fish. J Fish Dis 26:563-574

Ostland VE, McGrogan DC, Ferguson HW (1997) Cephalic osteochondritis and necrotic scleritis in intensively reared salmonids associated with Flexibacter psychrophilus. J Fish Dis 20:443-450

Rangdale RE (1995) Studies on rainbow trout fry syndrome (RTFS). PhD thesis, Ministry of Agriculture, Fisheries and Food, Weymouth, and University of Stirling

Santos Y, Huntly PG, Turnbull A, Hastings TS (1992) Isolation of Cytophaga psychrophila (Flexibacter psychrophilus) in association with rainbow trout mortality in the United Kingdom. Bull Eur Assoc Fish Pathol 12:209-210

Schmidtke LM, Carson J (1995) Characteristic of Flexibacter psychrophilus isolated from Atlantic salmon in Australia. Dis Aquat Org 21:157-161

Secades P, Alvarez B, Guijarro JA (2001) Purification and characterization of a psychrophic, calcium-induced, growthphase-dependent metalloprotease from the fish pathogen Flavobacterium psychrophilum. Appl Environ Microbiol 67:2436-2444

Toranzo AE, Barja JL (1993) Fry mortality syndrome (FMS) in Spain: isolation of the causative bacterium Flexibacter psychrophilus. Bull Eur Assoc Fish Pathol 13:30-32

Wakabayashi H, Toyama T, Iida T (1994) A study on serotyping of Cytophaga psychrophila isolated from fishes in Japan. Fish Pathol 29:101-104

Submitted: September 13, 2004; Accepted: May 9, 2005 Proofs received from author(s): October 14, 2005 